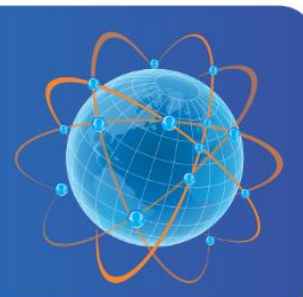

\title{
Studi Deskriptif Tentang Loyalitas Peserta Grup WhatsApp
}

Authors : Rachmaniar, Renata Anisa

Published by : Departemen of Sociology, Faculty of Social and Political Science, Universitas Padjadjaran

Accepted : November 2017; Approved : December 2017

Sosiogobal: Jurnal Pemikiran dan Penelitian Sosiologi is the Department of Sociology, Faculty of Social and Political Science, Universitas Padjadjaran flagship journal. The Sosioglobal journal founded in 2016 with the mission to publish original works of interest to the discipline of sociology in general, sociological thinking, new theoretical developments, results of research that enhance understanding of fundamental social processes, and methodological innovations. We are welcome a research article, working paper, theoretical/conceptual and methodological review to submit to our journal. In addition, we are accept relevant book review that currently publish and enrich sociological perspectives. Please submit article to http://jurnal.unpad.ac.id/sosioglobal

To cite this article :

Rachmaniar, Renata Anisa.2017. Studi Deskriptif Tentang Loyalitas Peserta Grup WhatsApp.

Sosioglobal : Jurnal Pemikiran dan Penelitian Sosiologi 2(1):32-39. 


\title{
STUDI DESKRIPTIF TENTANG LOYALITAS PESERTA GRUP WHATSAPP
}

\author{
Rachmaniar ${ }^{1}$, Renata Anisa ${ }^{2}$ \\ Prodi Ilmu Komunikasi, Fakultas Ilmu Komunikasi, Universitas Padjadjaran \\ rachmaniar@unpad.ac.id
}

\begin{abstract}
ABSTRAK
Media Sosial WhatsApp atau yang biasa disingkat WA sudah menjadi sarana berkomunikasi yang popular saat ini. Di Indonesia pertumbuhan WhatsApp termasuk yang paling tinggi. Berdasarkan hasil pengamatan, rata-rata orang yang memiliki WhatsApp, memiliki grup WhatsApp, dan ada yang bertahan untuk tetap berada dalam suatu grup WhatsApp tertentu. Atas hal tersebut, penulis tertarik untuk memahami loyalitas peserta grup WhatsApp. Tujuan dari penelitian ini adalah untuk mengetahui alasan seseorang bertahan dalam suatu grup WhatsApp tertentu. Teori yang digunakan dalam penelitan ini adalah teori motivasi dari Abraham Marslow dan Teori Pertukaran Social dari Thibault dan Kelley's. Metode yang digunakan dalam penelitian ini adalah metode kualitatif dengan pendekatan deskriptif untuk mengetahui loyalitas peserta grup WhatsApp. Informan utama dari penelitian ini yaitu pemilik WhatsApp berusia dewasa muda. Teknik pengumpulan data yang dilakukan melalui wawancara mendalam, observasi partisipatif pasif, dan studi literatur. Hasil penelitian ini menunjukkan bahwa alasan loyalitas seseorang berada dalam grup WhatsApp: a) bonding, b) sharing, c) kemudahan berhubungan, dan d) kebutuhan informasi.
\end{abstract}

Kata kunci: whatsapp, grup, loyalitas, peserta

\begin{abstract}
WhatsApp Social Media or commonly abbreviated as WA has become a popular means of communicating today. In Indonesia WhatsApp growth is among the highest. Based on observations, the average person who has WhatsApp, has the WhatsApp group, and some are persisted to stay within a certain WhatsApp group. Based that the fact, the author is interested to understand the loyalty of the group WhatsApp participants. The purpose of this study was to find out why one survives in a particular WhatsApp group. The purpose of this study was to find out one's loyalty lies within the WhatsApp group. The theory used in this research is need hierarchy theory from Abraham Marslow and Social Exchange Theory from Thibault and Kelley's. The method used in this research is a qualitative method with descriptive approach to know the loyalty of WhatsApp group participants. The main informant of this research is the owners of WhatsApp with young adulthood categories. Data collection techniques are conducted through in-depth interviews, passive participatory observation, and literature studies. The results of this study indicate that the reasons for loyalty are in the WhatsApp group: a) bonding, b) sharing, c) ease of contact, and d) information needs.
\end{abstract}

Keywords : whatsapp, group, loyalty, participants

2. Prodi Hubungan Masyarakat, Fakultas Ilmu Komunikasi, Universitas Padjadjaran 


\section{PENDAHULUAN}

Media Sosial Whats App atau yang biasa disingkat WA sudah menjadi sarana berkomunikasi yang popular saat ini. Tercatat sudah 1 miliar pengguna aktif bulanan per Februari 2016 ${ }^{1}$, dengan 42 miliar pesan dan 250 juta video dikirim lewat layanan tersebut per harinya. ${ }^{2}$ Ini berarti satu dari tujuh orang di dunia menggunakan layanan media sosial WhatsApp.

Di Indonesia pertumbuhan Whats $A p p$ termasuk yang paling tinggi, bahkan Whats $A p p$ telah menjadi salah satu aplikasi terpopuler di kalangan pengguna mobile tanah Air. Hal ini disebabkan karena masyarakat Indonesia senang berbicara dibanding masyarakat di negaranegara lain.

"(Indonesia) masuk dalam lima besar wilayah yang pertumbuhannya paling tinggi," tulis pendiri WhatsApp, Brian Acton, dalam korespondensi e-mail dengan Jakarta Post. Acton menambabkan bahwa WhatsApp telah menjadi salab satu aplikasi terpopuler di kalangan pengguna mobile Tanah Air. "Whats App adalah aplikasi berbayar nomor satu di iPhone serta nomor dua untuk kategori aplikasi gratis di Android dan BlackBerry." Tingginya angka penggunaan WhatsApp di Indonesia, menurut juru bicara Neeraj Arora, adalah karena penduduknya "sangat suka ngobrol dibanding di negara-negara lain". "Aplikasi ini dipakai berkali-kali setiap harinya," ujar Arora."

Hal ini tampak bukan dari komunikasi antar satu orang dengan orang lainnya, tetapi juga tampak ketika mereka berada dalam grup. Tidak mengherankan jika setiap orang yang memiliki Whats App, bergabung dalam beberapa grup Whats $A p p$.

Berdasarkan yang penulis amati, rata-rata orang yang memiliki Whats $A p$, memiliki grup Whats $A p p$. Mereka tergabung dalam grup Whats $A p p$ dengan jumlah peserta besar, atau tergabung dalam grup WhatsAppdengan jumlah peserta kecil.

Untuk grup WhatsAppdengan jumlah peserta besar, rata-rata anggotanya diatas 50 orang. Untuk grup Whats $A p p$ dengan jumlah peserta sangat kecil, anggotanya hanya 3 orang.

Media Sosial WhatsApp memiliki layanan chat grup. Hal ini membuat setiap pengguna Whats Appdapat membuat grup Whats App atau tergabung dalam suatu grup Whats App. Untuk satu grup Whats App, chat grup nya memampukan pengguna Whats App chatting dengan 256 orang sekaligus. ${ }^{4}$

Untuk beberapa grup Whats $A p p$ yang pernah diikuti penulis, disini terlihat ada beberapa orang yang masih mempertahankan dirinya untuk tetap berada dalam suatu grup WhastApp tertentu atau bahkan keluar dari suatu grup Whats $A p p$.

1Yusuf, O. (2016). Angka Fantastis Facebook. Messenger dan Whats App. Diakses pada 9 Agustus 2016, dari http://tekno.kompas.com/read/2016/04/13/13160107/Angka.Fantastis.Facebook.Messenger.dan. WhatsApp 2BBC Indonesia. (2016). Pengguna WhatApp mencapai 1 miliar tiap bulan. Diakses pada 9 Agustus 2016, dari http://www.bbc.com/indonesia/majalah/2016/02/160202_majalah_bisnis_whatsapp.

${ }^{3}$ Yusuf, O. (2013). Pendiri Whats App Komentari Orang Indonesia. Diakses pada 9 Agustus 2016,

darihttp://tekno.kompas.com/read/2013/06/25/08514583/Pendiri.WhatsApp.Komentari.Orang.Indonesia.

${ }^{4}$ WhatsApp. Diakses pada 9 Agustus 2016, dari https://www.whatsapp.com/faq/id/android/23776567. 


\section{Rachmaniar, Renata Anisa}

Atas pengalaman tersebut, penulis menjadi tertarik untuk mengetahui alasan seseorang bertahan dalam suatu grup WhatsApp tertentu. Untuk menjawab pertanyaan tersebut, penulis menggunakan penelitian kualitatif dengan tradisi penelitian deskriptif, dan teori motivasi dari Abraham Marslow serta teori pertukaran social dari Thibault and Kelley's.

\section{METODE PENELITIAN}

Penelitian kualitatif adalah penelitian yang bersifat empiris (dapat diamati dengan pancaindera sesuai dengan kenyataan), dengan pengamatan atas data tidak didasarkan pada ukuran-ukuran matematis yang terlebih dulu ditetapkan peneliti dan harus disepakati (direplikasi) oleh pengamatan lain, tetapi berdasarkan ungkapan subjek penelitian, sebagaimana yang dikehendaki dan dimaknai oleh subjek penelitian. Pendekatan kualitatif menggunakan konsep kealamiahan (kecermatan, kelengkapan, atau orisinalitas) data dan apa yang sebenarnya terjadi di lapangan.

Pendekatan kualitatif terutama layak untuk menelaah sikap atau perilaku dalam lingkungan yang agak artifisial, seperti dalam survei atau eksperimen. Peneliti kualitatif lebih menekankan proses dan makna ketimbang kuantitas, frekuensi atau intensitas (yang secara matematis dapat diukur), meskipun peneliti tidak mengharamkan statistik deskriptif dalam bentuk distribusi frekuensi atau presentase untuk melengkapi analisis datanya (Mulyana, 2007:11).

Sementara tradisi penelitian deskriptif adalah penelitian yang berusahamendeskripsikan suatu gejala, peristiwa, kejadian yang terjadi pada saat sekarang (Sujana dan Ibrahim, 1989:65). Penelitian deskriptif (descriptive research) adalah penelitian yang ditujukan untuk menggambarkan fenomena-fenomena yang ada, yang berlangsung pada saat ini atau saat yang lampau, dengan karakteristik sebagai berikut:

1. Penelitian deskriptif cenderung menggambarkan suatu fenomena apaadanya dengan cara menelaah secara teratur-ketat, mengutamakanobyektivitas, dan dilakukan secara cermat.

2. Tidak adanya perlakuan yang diberikan atau dikendalikan, dan tidakadanya uji $b$ (Furchan, 2004:54).

Penelitian deskriptif mempunyai ciri-ciri:

1. Berhubungan dengan keadaan yang terjadi saat itu.

2. Menguraikan satu variabel saja atau beberapa variabel namun diuraikan satu persatu

3. Variabel yang diteliti tidak dimanipulasi atau tidak ada perlakuan(treatment)

(Kountur, 2003:105)

34 SUSIOGLLBAL : Jurnal Pemikiran dan Penelitian Sasiologi, Val. 2, No. I, Desember 2017 


\section{KERANGKA KONSEP/TEORITIS}

Teori yang digunakan adalah teori motivasi dari Abraham Marslow dan teori pertukaran social dari Thibault dan Kelley's. Dalam teori motivasi dari Abraham Marslow disebutkan bahwa Setiap manusia mempunyai needs (kebutuhan, dorongan, intrinsic dan extrinsic factor), yang pemunculannya sangat tergantung dari kepentingan individu. Sondang Siagian P dalam Manajemen Sumber Daya Manusia menyebut bahwa A. Maslow membuat needs hierarchy theory untuk menjawab tentang tingkatan kebutuhan manusia tersebut.

Adapun kebutuhan manusia tersebut adalah:

1. Kebutuhan Fisiologis (Physiological Needs)

Perwujudan dari kebutuhan fisiologis adalah kebutuhan pokok manusia yaitu sandang, pangan, papan, dan kesejahteraan individu. Kebutuhan ini dipandang sebagai kebutuhan yang paling mendasar, karena tanpa pemenuhan kebutuhan tersebut, seseorang tidak dapat dikatakan hidup normal.

2. Kebutuhan Rasa Aman (Safety Needs)

Kebutuhan keamanan harus dilihat dalam arti luas, tidak hanya diartikan dalam arti keamanan fisik semata, tetapi juga keamanan psikologis dan perlakuan yang adil dalam pekerjaan.

3. Kebutuhan Sosial (Social Needs)

Manusia pada hakekatnya adalah makhluk sosial, tidak dapat memenuhi kebutuhan sendiri dan pasti memerlukan bantuan orang lain, sehingga mereka harus berinteraksi dalam memenuhi kebutuhan tersebut. Kebutuhan sosial tercermin dalam empat bentuk perasaan, yaitu:

a. Kebutuhan akan perasaaan diterima orang lain dengan siapa ia bergaul dan berinteraksi dalam organisasi dan demikian ia memiliki sense of belonging yang tinggi.

b. Harus diterima sebagai kenyataan bahwa setiap orang mempunyai jati diri yang khas dengan segala kelebihan dan kekurangannya. Dengan jati dirinya itu, setiap manusia merasa dirinya penting, artinya ia memiliki sense of importance.

c. Kebutuhan akan perasaan maju dan tidak akan gagal sering disebut sense of accomplishment. Tidak ada orang yang merasa senang apabila ia menemui kegagalan, sebaliknya, ia senang apabila ia menemui keberhasilan.

d. Kebutuhan akan perasaan diikutsertakan (sense of participation). Kebutuhan ini sangat terasa dalam hal pengambilan keputusan yang menyangkut diri dan tugas sendiri. Sudah barang tentu bentuk dari partisipasi itu dapat beraneka ragam seperti dikonsultasikan, diminta memberikan informasi, didorong memberikan saran. 
4. Kebutuhan akan Harga Diri (Esteem Needs)

Semua orang memerlukan pengakuan atas keberadaan statusnya oleh orang lain. Situasi yang ideal adalah apabila prestise itu timbul akan menjadikan prestasi seseorang. Akan tetapi tidak selalu demikian, karena dalam hal ini semakin tinggi kedudukan seseorang, maka akan semakin banyak hal yang digunakan sebagai simbol statusnya itu.

5. Aktualisasi Diri (Self Actualization)

Hal ini dapat diartikan bahwa dalam diri seseorang terdapat kemampuan yang perlu dikembangkan, sehingga dapat memberikan sumbangsih yang besar terhadap kepentingan organisasi.

Sementara dalam teori pertukaran sosial (social exchange theory) disebutkan bahwa pada dasarnya orang memandang hubungan mereka dalam konteks ekonomi dan mereka menghitung pengorbanan dan membandingkannya dengan penghargaan yang didapatkan dengan meneruskan hubungan itu.

Pengorbanan (cost) adalah elemen dari sebuah hubungan yang memiliki nilai negatif bagi seseorang. Contohnya rasa tertekan dan tegang. Penghargaan (reward) adalah elemen-elemen dalam sebuah hubungan yang memiliki nilai positif. Contohnya saling pengertian dan memahami (West \& Turner, 2008:216).

Sudut pandang pertukaran sosial berpendapat bahwa orang menghitung nilai keseluruhan dari sebuah hubungan dengan mengurangkan pengorbanannya dari penghargaan yang diterima (Monge \& Contractor dalam West \& Turner, 2008:216).

Nilai $=$ Penghargaan - pengorbanan

Hubungan yang positif adalah hubungan dimana nilainya merupakan angka positif. Maksudnya penghargaan lebih besar daripada pengorbanan. Hubungan dimana nilainya adalah angka negatif (pengorbanan melebihi penghargaan) cenderung negaitif untuk para partisipannya.

Teori pertukaran sosial bahka melangkah lebih jauh dengan memprediksi bahwa nilai (worth) dari sebuah hubungan mempengaruhi nilai akhir (outcome) atau apakah orang akan meneruskan suatu hubungan atau mengakhirinya. Hubungan yang positif biasanya dapat diharapkan untuk bertahan, sedangkan hubungan yang negatif mungkin akan berakhir.

\section{PEMBAHASAN}

Alasan dalam Kamus Besar Bahasa Indonesia berarti dasar, asas, hakikat; dasar bukti (keterangan) yang dipakai untuk menguatkan pendapat (sangkalan, perkiraan, dsb); yang menjadi pendorong (untuk berbuat).

36 | SOSIOGLLBAL : Jurnal Pemikiran dan Penelitian Sasiologi, Vol. 2, No. I, Desember 2017 
Alasan informan tetap bertahan dalam grup di media social WhatsApp adalah (1) Gi karena untuk merekatkan tali pertemanan, silaturahmi, berdiskusi, dan bertukar informasi. (2) Ar untuk lebih mudah dalam berhubungan, keep contact, dan karena kebutuhan mendapat informasi. (3) Ta untuk memudahkan jaringan komunikasi dan tetap mengetahui informasi terbaru dari kelompok. (4) Put karena keperluan atas informasi. (5) Ci karena lingkaran pertemanan, kebutuhan, dan kemudahan dalam koordinasi. (6) Ji karena mempermudah komunikasi, ramai dan seru, dapat berbagi dan berdiskusi tentang banyak hal dengan beberapa orang sekaligus. (7) Ros karena dapat mempermudah komunikasi dan mengetahui informasi terbaru, serta merekatkan hubungan pribadi dengan kelompok. Alasan-alasan tersebut pada dasarnya dapat dikelompokkan menjadi 4 alasan besar:

1. Bonding

2. Sharing

3. Kemudahan berhubungan

4. Kebutuhan informasi

Keempat alasan tersebut jika dilihat dari teori motivasi Abraham Marslow termasuk kedalam kebutuhan social - sense of belonging, sense of importance, sense of accomplishment, dan sense of participation.

1. Sense of belonging

Kebutuhan akan perasaaan diterima orang lain dengan siapa ia bergaul dan berinteraksi dalam organisasi.

2. Sense of importance

Harus diterima sebagai kenyataan bahwa setiap orang mempunyai jati diri yang khas dengan segala kelebihan dan kekurangannya. Dengan jati dirinya itu, setiap manusia merasa dirinya penting.

3. Sense of accomplishment

Kebutuhan akan perasaan maju dan tidak akan gagal. Tidak ada orang yang merasa senang apabila ia menemui kegagalan, sebaliknya, ia senang apabila ia menemui keberhasilan.

4. Sense of participation

Kebutuhan akan perasaan diikutsertakan. Kebutuhan ini sangat terasa dalam hal pengambilan keputusan yang menyangkut diri dan tugas sendiri. Sudah barang tentu bentuk dari partisipasi itu dapat beraneka ragam seperti dikonsultasikan, diminta memberikan informasi, didorong memberikan saran. 
Dengan keempat-empatnya menekankan pada alasan internal - menyangkut bagian dalam diri.

Hedonisme, salah satu paham filsafat etika, memandang manusia sebagai makbluk yang bergerak untuk memenubi kepentingan dirinya, mencari kesenangan dan menghindari penderitaan (Rakhmat, 1998:21).

Temuan dari penelitian ini adalah bagaimanapun keberadaan seseorang dalam grup di media social WhatsApp pada dasarnya hanya untuk memenuhi kebutuhan pribadinya - seseorang ingin mendapatkan sesuatu dari grup, bukan seseorang ingin memberikan sesuatu bagi grup. Hal ini sejalan juga dengan teori pertukaran social dari Thibault and Kelley's yang menyatakan bahwa nilai (worth) dari sebuah hubungan akan mempengaruhi nilai akhir (outcome) atau apakah orang akan meneruskan suatu hubungan atau mengakhirinya. Hubungan yang positif biasanya dapat diharapkan untuk bertahan, sedangkan hubungan yang negatif mungkin akan berakhir.

\section{SIMPULAN}

Berdasarkan pemaparan dalam bab-bab sebelumnya, dari hasil data penelitian dapat diambil simpulan sebagai berikut:

1. Alasan berada dalam grup di media social WhatsApp adalah: a) bonding, b) sharing, c) kemudahan berhubungan, dan d) kebutuhan informasi.

2. Keberadaan seseorang dalam grup di media social WhatsApp pada dasarnya hanya untuk memenuhi kebutuhan pribadinya - seseorang ingin mendapatkan sesuatu dari grup, bukan seseorang ingin memberikan sesuatu bagi grup.

\section{DAFTAR PUSTAKA}

BBC Indonesia. 2016. Pengguna WhatApp mencapai 1 miliar tiap bulan. Diakses pada 9 Agustus 2016, dari http://www.bbc.com/indonesia/majalah/2016/02/ 160202_majalah_bisnis_whatsapp

Furchan, A. 2004. Pengantar Penelitian dalam Pendidikan. Yogyakarta: Pustaka Pelajar Offset

Kountur, Ronny. 2003. Metode Penelitian Untuk Penulisan Skripsi dan Tesis. Jakarta: PPM

Mulyana, Deddy. \& Solatun.2007. Metode Penelitian Komunikasi. Bandung: PT. Remaja Rosdakarya.

Rakhmat, J. 1998. Psikologi Komunikasi. Bandung: Remaja Rosdakarya.

Siagian, Sondang P. 1996. Manajemen Sumber Daya Manusia. Jakarta: Bumi Aksara

Sudjana, Nana. \& Ibrahim. 1989. Penelitian dan Penilaian Pendidikan. Bandung: Sinar Baru

West, Richard. \& Turner, Lynn H.2008. Pengantar Teori Komunikasi: Analisis dan Aplikasi (Buku 2) (Edisi 3). Jakarta: Salemba Humanika

WhatsApp. Diakses pada 9 Agustus 2016, dari https://www.whatsapp.com/faq/id/ android $/ 23776567$ 
Yusuf, O. 2013. Pendiri Whats App Komentari Orang Indonesia. Diakses pada 9 Agustus 2016, darihttp://tekno.kompas.com/read/2013/06/25/08514583/

Pendiri.WhatsApp.Komentari.Orang.Indonesia.

Yusuf, O. 2016. Angka Fantastis Facebook. Messenger dan WhatsApp. Diakses pada 9 Agustus 2016, dari http://tekno.kompas.com/read/2016/04/13/13160107/

Angka.Fantastis.Facebook.Messenger.dan.WhatsApp 